
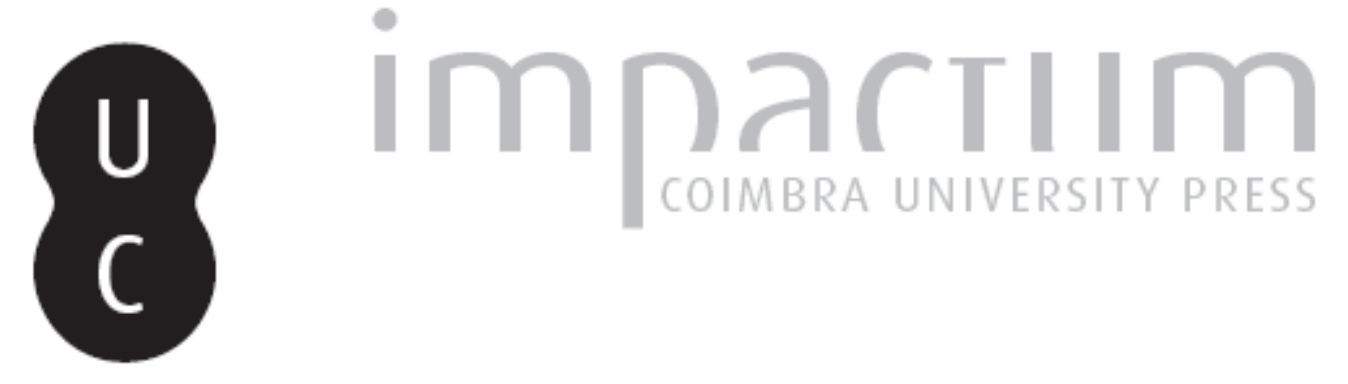

Online news coverage of the Eurozone crisis: discussion in Italy and Spain

Autor(es): $\quad$ Albertini, Marta

Publicado por: Imprensa da Universidade de Coimbra

URL persistente:

URI:http://hdl.handle.net/10316.2/38255

DOI:

DOI:http://dx.doi.org/10.14195/1647-8622_15_6

Accessed : $\quad$ 26-Apr-2023 13:19:32

A navegação consulta e descarregamento dos títulos inseridos nas Bibliotecas Digitais UC Digitalis, UC Pombalina e UC Impactum, pressupõem a aceitação plena e sem reservas dos Termos e Condições de Uso destas Bibliotecas Digitais, disponíveis em https://digitalis.uc.pt/pt-pt/termos.

Conforme exposto nos referidos Termos e Condições de Uso, o descarregamento de títulos de acesso restrito requer uma licença válida de autorização devendo o utilizador aceder ao(s) documento(s) a partir de um endereço de IP da instituição detentora da supramencionada licença.

Ao utilizador é apenas permitido o descarregamento para uso pessoal, pelo que o emprego do(s) título(s) descarregado(s) para outro fim, designadamente comercial, carece de autorização do respetivo autor ou editor da obra.

Na medida em que todas as obras da UC Digitalis se encontram protegidas pelo Código do Direito de Autor e Direitos Conexos e demais legislação aplicável, toda a cópia, parcial ou total, deste documento, nos casos em que é legalmente admitida, deverá conter ou fazer-se acompanhar por este aviso.

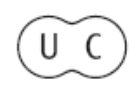




\section{comunicação, jornalismo e espaço público na era digital}

\section{ESTUD OSD OSÉCULO}

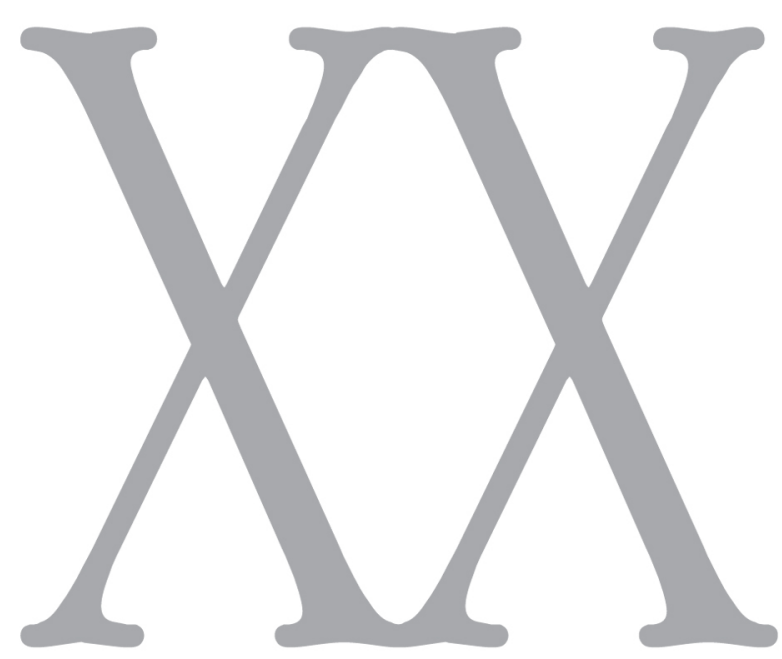

número 15 • 2015

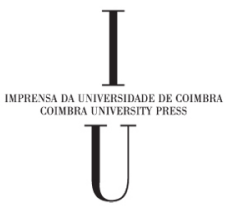




\title{
Online news coverage of the Eurozone crisis: discussion in Italy and Spain
}

\author{
Marta Albertini
}

Marta Albertini, Master in Science in Communication Studies in Vrije Universiteit Brussel. Email: alb.martalb@gmail.com

http://dx.doi.org/10.14195/1647-8622_15_6 
COBERTURA NOTICIOSA DA CRISE DA ZONA EURO: O DEBATE EM ITÁLIA E EM ESPANHA

Foram amplamente publicadas notícias sobre a crise da zona euro em todos os jornais nacionais europeus em 2012, especialmente em Itália e em Espanha. Contudo, esses artigos nem sempre ilustraram uma perspetiva europeia comum. Pelo contrário, limitaram-se a mostrar o choque ideológico entre os países da UE. Com base numa análise de artigos online publicados pela $L a$ Repubblica e pelo El Pais, entre maio e julho de 2012, e numa explicação dos debates que se geraram no seio da comunidade de leitores nas plataformas digitais dos jornais, o presente artigo pretende identificar os aspetos comuns e os aspetos divergentes relativos à cobertura noticiosa efetuada pelos jornais europeus.

Palavras-chave: Jornalismo digital, Crise da Eurozona, Jornalismo Europeu, Uniāo Europeia, Internet.
ONLINE NEWS COVERAGE OF THE EUROZONE CRISIS: DISCUSSION IN ITALY AND SPAIN

News about the Eurozone crisis were widely published by all European national newspapers in 2012, particularly in Italy and Spain. However, these articles did not always depict a common European perspective, but rather showed a clash of views among EU countries. Through an analysis of the online articles published by La Repubblica and El Pais from May to July 2012, and an explanation of the debates generated within the readers community in the newspapers' platforms, this article aims at identifying common and divergent features of EU news coverage across online European newspapers.

Keywords: Online Journalism, Eurozone crisis, European Journalism, European Union, Internet.
COUVERTURE EN LIGNE DE LA CRISE DE ZONE EURO: DISCUSSION EN ITALIE ET EN ESPAGNE

Les informations à propos de la crise la zone Euro furent amplement publiées par tous les journaux nationaux européens en 2012, notamment en Italie et en Espagne. Toutefois, ces articles n'illustraient pas une perspective Européenne commune, mais démontraient plutôt des points de vue opposés entre les pays de l'UE. A travers une analyse des articles en ligne, publiés par La Repubblica et El Pais, de mai à juillet 2012, et une explication des débats engendrés parmi la communauté des lecteurs dans les plateformes des journaux, cet article vise l'identification des caractéristiques communes et divergentes de la couverture des informations de l'UE à travers les journaux en ligne Européens.

Mots-clefs: Journalisme numérique; Crise de l'Eurozone; Journalisme Européen; Union Européenne; Internet; 


\section{Introduction}

Since 2009, the European Union (EU) has been suffering from a serious economic crisis that has severely hit some of its Member States. National as well as European policy makers have been trying very hard to find solutions in order to put an end to this crisis through new initiatives that EU citizens find difficult to accept. As a matter of fact, the austerity policies and the rigorous measures and cuts decided by governments have often been rejected by their citizens, who have protested in major squares of many European cities over these years.

The lack of European media has made national media, such as television, newspapers and radio, the main channels where EU news is presented and analysed. ${ }^{1}$ However, the national perspective still plays a huge role in defining the causes of the crisis and the various national reactions. Moreover, what is not clear yet is the role of online newspapers. Even if it is difficult to talk about a precise percentage, it has been proved that nowadays European readership is moving from offline broadsheets to national newspapers' online platforms and that the young generation considers the Internet as a trustworthy news source. ${ }^{2}$ The role of the newspaper is therefore facing a change: the relation with readers is no longer one-to-many as the release of the news is followed by different online receptions. ${ }^{3}$

This article attempts to give an outlook of the way news about the Eurozone crisis have been depicted and received in order to underline whether newspapers are using online features and tools in a proper way, and whether users are interested in reading and sharing their opinions about the news that concern the European Union. Through an analysis of the online articles published by La Repubblica and El Pais from May to July 2012, and an explanation of the debates generated within the readers community in the newspapers' platforms, this article aims to identify common and divergent features of EU news coverage across the online versions of Italian and Spanish newspapers.

\section{Spain and Italy: a political insight in a time of crisis}

In 2012, the European Union was facing a moment of hardship and critical decision choices. The French elections resulted in a strong victory for François Hollande while in Greece, the elections in May 2012 lacked a majority and new elections were held in the middle of June. Northern European countries and Germany were the Member States less involved in the Eurozone crisis, whereas Spain and Italy feared the domino-effect from the economic situation in Greece. In June 2012, the European Council was due

\footnotetext{
${ }^{1}$ DE VREESE, Claes H. - "The EU as a public sphere". Living Reviews in European Governance. Vienna. ISSN 1813-856X. N. 03, Vol. 2 (2007) p. 7- 8

${ }^{25}$ IMON, Jean Paul - "The Newspaper Publishing Industry, Statistical, Ecosystems and Competitiveness Analysis of the Media and Content Industries". Joint Research Centre. Luxembourg. ISSN 1831-9424. Report EUR 25277 EN (2012) p. 43.

${ }^{3}$ DOMINGO, David [et al.]- "Participatory Journalism Practices in the media and beyond - An international comparative study of initiatives in online newspapers". Journalism Practice. ISSN 1751-2786. Vol. 2, No 3 (2008) p. 329.
} 
to decide important matters related to the European Monetary Union and new growth measures in order to reduce unemployment and push the European economy to a recovery from the crisis. The economic crisis provoked an economic recession with social consequences, and was considered a contagious disease for Eurozone countries, especially in the South of Europe. Spain and Italy, two countries whose economies are huge and financial importance undoubtedly high, were in a critical situation. At the time, austerity policies and reforms seemed to be the best way to prevent a European economic collapse.

\section{Italy: a political and socio-economic outlook}

In Italy, the critical situation in the second semester of 2011 led to the end of Berlusconi's government and the arrival of Mario Monti as the new technocratic Prime Minister. ${ }^{4}$ The main problem was the fluctuating difference between the Italian and German spread that hit 552 in 9 November 2011, a financial problem that required more guarantees to encourage foreign shareholders to invest in the country. ${ }^{5}$ Since the debt started to reach unsustainable levels, financial media and economists considered Italian bonds as risky investments instead of sure assets. ${ }^{6}$ Even if the banking system did not crash during the American bubble burst, the Italian situation led to limited financial exposures and private loans access, which reduced the possibility for companies to put an end to the recession. ${ }^{7}$ As a consequence, production and exports were declining. However, Italy's main economic problems were also related to a lack of labour and industrial reforms. ${ }^{8}$

Many analysts have seen the Italian economy as "the endgame of an eventual collapse of the common currency as it is too big to fail". "Since the end of 2011, the newly appointed Prime Minister Mario Monti has disclosed a radical and ambitious package named, "Salva Italia" [Saving Italy] which constituted in spending cuts and tax increases including unpopular decisions like augmenting the country's retirement age. ${ }^{10}$ The austerity measures have also included a sudden freeze on public sector

\footnotetext{
${ }^{4}$ CENCIG, Elisa - "Italy's economy in the euro zone crisis and Monti's reform Agenda". SWF Berlin Working Paper. FG 1 2012/05 (September 2012) p.3 [Consult. 6 Outubro de 2013]. Disponível em WWW: <URL: http://www.swp-berlin.org/fileadmin/contents/products/arbeitspapiere/Italy_Economy.pdf z.

${ }^{5}$ Ibidem, p. 17

${ }^{6}$ DI QUIRICO, Roberto - "Italy: the good, the bad and the ugly". Bulletin of Italian Politics. Vol. 2, No. 2, (2010) p. 3-19 [Consult. 7 Outubro de 2013]. Disponível em WWW: <URL: http://www.gla. ac.uk/media/media_191024_en.pdf>.

${ }^{7}$ Idem

${ }^{8}$ CENCIG, Elisa - "Italy's economy in the euro zone crisis and Monti's reform Agenda". SWF Berlin Working Paper. FG1 2012/05. (2012) p.8. [Consult. 6 Outubro de 2013]. Disponível em WWW: <URL:http:// www.swp-berlin.org/fileadmin/contents/products/arbeitspapiere/Italy_Economy.pdf>.

${ }^{9}$ HIDALGO, Juan Carlos - Looking at Austerity in Italy. Cato Institute. (2012) [Consult. 6 Outubro de 2013]. Disponível em WWW: <URL: http://www.cato.org/blog/looking-austerity-italy>

${ }^{10}$ CENCIG, Elisa - Italy's economy in the euro zone crisis and Monti's reform Agenda. SWF Berlin: Working Paper FG 1 2012/ 05. (2012) p. 33 [Consult. 6 Outubro de 2013]. Disponível em WWW: <URL: http://www.swp-berlin.org/fileadmin/contents/products/arbeitspapiere/Italy_Economy.pdf >
} 
salaries and an intense fight against tax evasion. ${ }^{11}$ Despite the implementation of this package, in 2012 new fears surfaced every day over the debt-burdened Italian economy as European policy makers struggled to prevent the escalation of the crisis in the Eurozone's third largest economy. Even though Monti implemented austerity measures and regulatory reforms, the economy seemed to have been sliding much deeper into recession during his term, which led to the technocratic government calling for elections in early $2013 .^{12}$

\section{Spain: a political and socio-economic outlook}

The real economic difficulties in Spain began in 2008 and became acute after 2010 when the Eurozone debt crisis reached its greatest peak. This is when the Spanish real estate market crashed and when major national companies faced bankruptcy. ${ }^{13}$ In 2009 , Spain's GDP $(-3,6 \%)$ contracted for the first time after nearly two decades and the country officially entered a recession period. ${ }^{14}$ In March 2012, youth unemployment increased significantly reaching the unprecedented 53,2\%. ${ }^{15}$ The austerity measures, that aimed to put an end to Spain's critical situation, have without doubt been very harsh in the recent past. Citizens have reacted in a dynamic way to their country's deep recession through massive protests and active manifestations. ${ }^{16}$ However, jobless citizens have not been the only concern, as Spain's banking system has also faced an extremely critical situation. As a result, from 2010 most of the Spanish banks' credit rankings have been progressively downgraded to junk status. ${ }^{17}$ Unavoidably, important banks have since then expressed the need for financial guidance and support either through national initiatives or bailouts packages in order to cover

${ }^{11}$ Idem

${ }^{12}$ DONADIO, Rachel - "As a Premier Prepares to Depart, the Talk Is of Lost Opportunities". New York Times. Dec. 3 (2012) [Consult. 6 Outubro de 2013]. Disponível em WWW: <URL: http://www.nytimes. $\mathrm{com} / 2012 / 12 / 14 /$ world/europe/as-mario-monti-prepares-to-step-down-italians-express-disappointment. html?ref=topics >

${ }^{13}$ CARBALLO-CRUZ, Francisco - "Causes and Consequences of the Spanish Economic Crisis: Why the Recovery is Taken so Long?”. PANOECONOMICUS. 2011, 3, (2011) p. 309, [Consult. 30 Setembro de 2013]. Disponível em WWW: <URL:http://www.doiserbia.nb.rs/img/doi/1452-595X/2011/1452$-595 X 1103309$ C.pdf >

${ }^{14}$ SUAREZ, Javier - "The Spanish Crisis: Background and Policy Challenges”. CEMFI. (2010) p. 5 [Consult. 25 Setembro de 2013]. Disponível em WWW: <URL: http://www.cemfi.es/ -suarez/ The_Spanish_Crisis_JSuarez.pdf>

${ }^{15}$ EUROSTAT - “Unemployment Statistics”. (2012). [Consult. 25 Setembro de 2013]. Disponível em WWW: <URL:http://epp.eurostat.ec.europa.eu/statistics_explained/index.php/Unemployment_statistics>.

${ }^{16}$ The 15-M movement, known as the idignados, demanded radical alterations of austerity measures in Spain becoming famous all over the the world. EL PAIS - "La manifestación de 'indignados' reúne a varios miles de personas en toda España”. (2011) [Consult. 6 Setembro de 2013]. Disponível em WWW: <URL: http://elpais.com/elpais/2011/05/15/actualidad/1305447428_850215.html >.

${ }^{17}$ SUAREZ, Javier - The Spanish Crisis: Background and Policy Challenges. CEMFI. (2010) p. 19. [Consult. 25 Setembro de 2013]. Disponível em WWW: <URL: http://www.cemfi.es/ - suarez/ The_Spanish_Crisis_JSuarez.pdf>. 
their losses. ${ }^{18}$ In June 2012, urgent discussions with regards to the necessity of capital infusion into the banks of Spain made their apparition. At that point, EU policy makers announced that an international aid package of $€ 100$ billion could be made available with the aim to save the fragmented Spanish banking system. ${ }^{19}$ Spain accepted the rescue package at the end of June 2012. ${ }^{20}$

From offline to online newspapers

\section{Features of online news}

The shift from offline to online newspapers has showed the main changes that the Internet has made to readers' habits. Time and space are notably the most dominant changes. ${ }^{21}$ Before the transition to online platforms, news was produced following specific steps, which created a time-frame for the selling, reading and disposal of a printed newspaper. Since the release of online platforms, newspapers can constantly update the news by providing the reader with revised articles and immediate publications of breaking news. ${ }^{22}$ Furthermore, because of the development of different technological devices, people have started to read online newspapers on their mobile phones and portable instruments that allow them to read the news wherever they are. Additionally, due to the structure of the Internet, readers can decide which news they want to focus on. Indeed, in a moment of information abundance due to the increase of websites, news consumption has changed and readers can focus on published news by using filters and applications.

Stuart Allan identified three main characteristics of online news. ${ }^{23}$ The three features are: immediacy, in-depth and interactivity. ${ }^{24}$ According to Allan, online newspapers have the ability to release information immediately compared to other mass media, such as

\footnotetext{
${ }^{18}$ One example of Spanish banks that asked for a financial support to the State was Bankia, the fourth largest Spanish bank that went through nationalization in May 2012 and asked for a $€ 23,5$ billions aid to cover its losses. FINANCIAL TIMES - Spain to inject $€ 19$ bn into Bankia, (2012) [Consult. 30 Setembro de 2013]. Disponível em WWW: <URL:http://www.ft.com/intl/cms/s/0/27db02ec-a643-11e1-aef200144feabdc0.html\#axzz2gqqACvn4>

${ }^{19}$ COUNCIL OF THE EUROPEAN UNION - Eurogroup Statement on Spain. (2012) [Consult. 23 Setembro de 2013]. Disponível em WWW: <URL:http://www.consilium.europa.eu/uedocs/cms_data/docs/ pressdata/en/ecofin/130778.pdf>

${ }^{20}$ THE NEW YORK TIMES - Spain to accept rescue from Europe for its ailing banks. (2012) [Consult. 24 Setembro de 2013]. Disponível em WWW: <URL:http://www.nytimes.com/2012/06/10/business/ global/spain-moves-closer-to-bailout-of-banks.html? pagewanted=all $\geq$.

${ }^{21}$ nCASTELLS, Manuel; PARKS, Micheal; VAN DER HAAK, Bregtje - "The Future of Journalism: Networked Journalism”. International Journal of Communication. 6 (2012). Feature 2923-2938. p. 29332934. [Consult. 6 de Agosto de 2013]. Disponível em WWW: <URL: http://ijoc.org/index.php/ijoc/ article/viewFile/1750/832>.

${ }^{22}$ ALLAN, Stuart - Online News, Journalism and The Internet. London: McGraw Hill Education. 2006. ISBN 10033522121 1. p. 23-24.

${ }^{23}$ Ibidem

${ }^{24}$ Ibidem
} 
print press. ${ }^{25}$ Moreover, the Internet allows journalists to explain the facts in-depth, an element that is often not possible offline due to space limitations. ${ }^{26}$ Thanks to the third feature, interactivity, experts can answer to readers' questions immediately (Ibidem). After more than eighteen years following Allan's explanation, these three main elements characterise news' websites more than ever before. Besides that, the invention of social media, such as Facebook and Twitter, has increased the possibility for users to share and update their personal pages with breaking news, but also comment on them. As Domingo argues "Computer technology and the Internet allow users, as individuals or pools, to produce and distribute news items on the basis of their observations or opinions". ${ }^{27}$ In Europe, for example, social media has become an important channel where news is disseminated. Among young people, social media has become one of the first sources to retrieve information as the Standard Eurobarometer 76 reports. ${ }^{28}$ This process increments news dissemination, while immediacy and interactivity allow journalists to get news from these social media even before the news agencies release it.

Online newspapers and the online edition of the printed ones have become indispensable media and channels making news available to citizens. However, qualitatively speaking, not all newspapers are using all the Internet's features yet, as technological and professional issues obstacle the real power online newspapers could have. ${ }^{29}$

\section{The state of play of journalism in Europe}

Different ways of conducting journalism are crucial when it comes to understanding how journalism in Europe is depicting the European Union. As a matter of fact, the role of educating and informing citizens has great importance at European level. The lack of a pan-European medium or newspaper and the bureaucratic distance between citizens and EU institutions provide national newspapers, together with the other mass media, with the main role to reach citizens and inform them about current EU events. ${ }^{30}$ In Europe, journalism has been strongly attached to the nation-state,

${ }^{25}$ ALLAN, Stuart - Online News, Journalism and The Internet. London: McGraw Hill Education. 2006. ISBN 10033522121 1. p. 23-24. and ALLAN, Stuart - "The emerging forms and practices of online journalism”. In ALLAN, Stuart - Journalism: critical issues. Berkshire: Open Universiy Press, 2005. ISBN 033521475 4. p. 74-76.

${ }^{26}$ ALLAN, Stuart - Online News, Journalism and The Internet. London: McGraw Hill Education, 2006. ISBN 10033522121 1. p. 26-28.

${ }^{27}$ DOMINGO, David [et al.] - "Participatory Journalism Practices in the media and beyond - An international comparative study of initiatives in online newspapers". Journalism Practice. ISSN 1751-2786. Vol. 2, No 3 (2008). p. 331.

${ }^{28}$ EUROPEAN COMMISSION - "Media Use in the European Union". TNS Opinion \& Social - Standard Eurobarometer 76 (Autumn 2011) p.29-31. [Consult. 22 Setembro de 2013]. Disponível em WWW: <URL: http://ec.europa.eu/public_opinion/archives/eb/eb76/eb76_media_en.pdf>

${ }^{29}$ STEENSEN, Steen - "Online Journalism and the promises of new technologies - A critical review and look ahead”. Journalism Studies. 12:3 (2010) p. 320. [Consult. 7 Setembro de 2013]. Disponível em WWW: <URL: http://dx.doi.org/10.1080/1461670X.2010.501151>

${ }^{30}$ MÖRÄ, Tuomo - "Ideals of European Public Sphere and EU Journalism". Sociologija. Mintis ir veiksmas. ISSN 1392-3358. 2008/3 (23) (2008) p. 88. [Consult. 4 Dezembro de 2012]. Disponível em WWW: <URL: file://C:/Users/UTENTE-PC/Downloads/CEEOL\%20Article.PDF >, MOUSSIS, Nicholas - Access to the 
but the birth of a European supranational entity, the European Union, has increased the range of reporting news and blurred the political boundaries. ${ }^{31}$ What the media landscape in Europe shows is a gap between the technocratic languages of the EU institutions, the wide knowledge that correspondents in Brussels possess and the way citizens learn about the European Union. ${ }^{32}$ The bridge should be a dissemination of news articles that, through neutral and legitimate forms, will explain to readers what is happening at European level. Nevertheless, as researches showed, the reality is constituted in brief articles, which contain abbreviations and bureaucratic words, lack of 'added value' and sometimes reflect a nationalistic perspective in the way EU decisions are reported. ${ }^{33}$

The technocratic character of European institutions is a difficulty correspondents should solve, as it results in unclear explanations of the political repercussions of the decision-making process. ${ }^{34}$ As a matter of fact, the specific policy discourse and rationale is interesting to a defined readership, and it requires a wide knowledge of the European Union. ${ }^{35}$ Moreover, as Lecheler, Martins and de Vreese argue, correspondents are strongly dissatisfied by the weak cooperation among the EU institutions and the predominant position of the Commission (Lecheler, Martins, de Vreese, 2011: 316). ${ }^{36}$ The results of their research show that, according to correspondents' replies, it is very difficult to cover EU affairs in a "qualitative" way due to the absence of a clear cooperative structure among the institutions. ${ }^{37}$

Nonetheless, with the development of the Internet, the EU institutions incremented their release of news through online platforms that spread press releases, speeches or memos about new EU events and decisions. Even though the European Commission is the main distributor of information, the Internet allows the Commission to add links to press releases, which connect users to the Council or European Parliament's pages.

European Union - Law, economics, policies. Brussels: Euroconfidential, 2011. ISBN 978-2-9601045-0-9. p. 177, VAN DE STEEG, Marianne - "Does a public sphere exist in the European Union? An analysis of the content of the debate on the Haider case". European Journal of Political Research. Vol. 45, Nr. 4 (2006) p. 610-611. [Consult. 7 Dezembro de 2012]. Disponível em WWW: <URL: http://onlinelibrary.wiley.com. ezproxy.vub.ac.be:2048/doi/10.1111/j.1475-6765.2006.00311.x/pdf>.

${ }^{31}$ STATHAM, Paul - "Make Europe News - How journalists view their role and media performance". Journalism. Vol. 9(4). (2008) p. 417 - 418 [Consult. 7 Dezembro de 2012]. Disponível em WWW: <URL:http://jou.sagepub.com.ezproxy.vub.ac.be:2048/content/9/4/398.full.pdf+html >

${ }^{32}$ Ibidem, p. 409-410.

${ }^{33} \mathrm{Idem}$

${ }^{34}$ BAISNEE, Olivier - "Can Political journalism exist at the EU level?". In KUHN, Raymond; NEVEN, Eric. - Political Journalism - New challenges, new practices. London: Routledge, 2002. ISBN 0-415-25813-8. p. 115.

${ }^{35}$ STATHAM, Paul - "Political Journalism and Europeanization: Pressing Europe?". Centre for European Political communication, Working Paper Series. Issue 13/06 (2006) p. 10. [Consult. 1 Agosto de 2013]. Disponível em WWW: <URL:http://www.eurpolcom.eu/exhibits/paper_13.pdf >

${ }^{36}$ LECHELER, Sophie, MARTINS, Ana Isabel, DE VREESE, Claes H. - "Information Flow and Communication Deficit: Perceptions of Brussels-Based Correspondents and EU Officials". Journal of European Integration. Vol. 34 (2012) p. 316. [Consult. 9 Agosto de 2013]. Disponível em WWW: <URL:http:// dx.doi.org/10.1080/07036337.2011.584345>

${ }^{37}$ Ibidem, p.312. 
Cornia questioned the possibility that national newspapers may nationalise the EU news. ${ }^{38}$ By analysing the Italian case, he supported the idea that Italian journalists report EU news from Brussels "by reading the EU events from a 'domestic' perspective and by actively searching for conflicts" ${ }^{39}$ On the other side, journalists believe that their work helps the citizens understand political decisions in Brussels, but also that they feel free to comment and critically question the EU news in line with the editorial perspective of the national newspapers. ${ }^{40}$

To conclude, journalism has faced a progressive change due to the technological developments and a shift towards a faster, immediate and more interactive news process. ${ }^{41}$ Contemporary to this change in the journalistic field, European nations have gone through a process of economic and political integration that has led EU institutions to hold more decisional power. ${ }^{42}$ Even the newsrooms from Brussels have followed these changes and the national press has increased the amount of reports in their newspapers, compared to the past. ${ }^{43}$ Newspapers have indeed an important role in reporting this political and economic integration, and the online editions have to cope with this role too. By taking into account the case of the online platforms of El Pais (ES) and La Repubblica (IT), this article tries to explain the challenges and limits that online national newspapers had when releasing EU news concerning the Eurozone crisis between May and July 2012.

\section{Research questions and methodology}

The rationale behind this research started with different general questions related to the role of Italian and Spanish online newspapers in covering EU news. In a critical political and economic moment for both countries, the discovery of how online newspapers influence the discussion of the news coming from the EU became one of the most crucial elements to better understand the role the online press plays in Italian and Spanish citizens' lives. The research is based on an empirical interpretative

\footnotetext{
${ }^{38}$ CORNIA, Alessio - "The Europeanization of Mediterranean Journalistic practices and the Italianization of Brussels: Dynamics of the interaction between EU institutions and nationalistic cultures". European Journal of Communication. Vol. 25, No4 (2010) p. 366 [Consult. 1 Março de 2013]. Disponível em WWW: <URL:http://ejc.sagepub.com/content/25/4/366.full.pdf >

${ }^{39}$ Ibidem, p. 376

${ }^{40}$ STATHAM, Paul - "Political Journalism and Europeanization: Pressing Europe?". Centre for European Political communication, Working Paper Series. Issue 13/06 (2006) p. 31-33 [Consult. 1 Agosto de 2013]. Disponível em WWW: <URL:http://www.eurpolcom.eu/exhibits/paper_13.pdf >

${ }^{41}$ BOCKZKWSKI, Pablo Javier - Digitizing the news - Innovation in online newspapers. Cambridge: MIT Press paperback edition, 2005. ISBN 9780262524391. p. 3-5 and ALLAN, Stuart - Online News, Journalism and The Internet. London: McGraw Hill Education, 2006. ISBN 10033522121 1. p. 23-26

${ }^{42}$ MCCORMICK, John - Understanding the European Union. New York: Palgrave Macmillan. 2008. ISBN 978-0-230-20102-6. p. 4-5

${ }^{43}$ TRENZ, Hans-Jörg - "Quo vadis Europe?” Quality newspapers struggling for European unity. Paper presented at the Workshop "One EU - Many Publics?". Stirling 5 - 6 February 2004. p. 18 [Consult. 7 Dezembro de 2012]. Disponível em WWW: <URL:http://www.sv.uio.no/arena/english/research/projects/ cidel/old/WorkshopStirling/PaperTrenz.pdf $>$
} 
method. The decision of conducting an interpretative analysis lies in the assumption that observing how a European "crisis" topic is depicted in newspapers would outline the main issues that hinder the fulfilment of a European journalism. Therefore, the main questions of this research reads: "Did online national newspapers in Italy and Spain cover news related to the Eurozone crisis in a national way?" and "Are national online newspapers in Italy and Spain the new channel for hosting an online European Journalism?"

\section{Methodology}

As mentioned before, the methodology used for this research is a critical interpretative analysis. The study required the selection of articles from the Italian online newspaper La Repubblica (www.repubblica.it) and the Spanish online newspaper El Pais (www. elpais.com). The main analysis consisted in interpreting and comparing how both online newspapers have depicted the events related to the Eurozone crisis; it also compared the articles' reception from both newspapers by looking at the number of comments and shares in social media for each article analysed. The time-frame selected is from May to July 2012. The selection of the articles was made through a preliminary coding on their respective online archives, by taking into consideration the main character of the study, the Eurozone crisis, and the articles' correlation with the European Union's decisions or events that occurred in the examined timeframe. Moreover, in order to compare better the two newspapers, the study took the midday express press releases produced by the European Commission into consideration in order to state which of the two newspapers better depicted the news from Brussels. ${ }^{44}$ Last but not least, in order to give a better explanation of the news coverage, statements and speeches from European Commissioners, the European Parliament and relevant EU officials have been analysed.

The author selected El Pais and La Repubblica by looking at the three models Hallin and Mancini have described, as well as other consistent researches on the Mediterranean journalism model related to European Journalism studies. ${ }^{45}$ La Repubblica and El Pais were both established in $1976 .{ }^{46}$ Furthermore, their online editions, which started in 1996, do not require fees to be read and are the mostly followed online in the selected

\footnotetext{
${ }^{44}$ Europa Press Room, European Commission Press Releases and the European institutions in EUROPEAN COMMISSION, Europa Press Room. (2013) [Consult. 2 Fevereiro de 2013]. Disponível em WWW: <URL:http://europa.eu/rapid/midday-express.htm>.

${ }^{45}$ HALLIN, Daniel C.; MANCINI, Paolo - Modelli di giornalismo. Mass media e politica nelle democrazie occidentali. Trad. Silvia Marini. Roma - Bari: Laterza, 2004. ISBN 88-420-7444-6 and CORNIA, Alessio - "The Europeanization of Mediterranean Journalistic practices and the Italianization of Brussels: Dynamics of the interaction between EU institutions and nationalistic cultures". European Journal of Communication. 25: 366 (2010) [Consult. 1 Março de 2013]. Disponível em WWW: <URL:http://ejc. sagepub.com/content/25/4/366.full.pdf>.

${ }^{46}$ GUNTHER, Richard; MONTERO, José Ramon; WERT, Jose Ignacio - "The media and politics in Spain: from Dictatorship to Democracy”. In MUGHAN, Anthony; GUNTHER, Richard - Media and Democracy: a comparative perspective. Cambridge: University Press, 2000. ISBN 978-0-521-77743-8. p. 45, and MARLETTI, Carlo; RONCAROLO, Franca - "Media Influence in the Italian Transition From a
} 
countries. ${ }^{47}$ The author selected the articles by using the following filters: crisis, European Union, Brussels. The final selection comprehended 205 articles, with a quite considerable difference between the Spanish newspapers (132 articles) and the Italian one (73). The quantitative difference was due to the lack of everyday articles about the EU in La Repubblica while the Spanish online newspaper offered more than one article per day related to what was happening at EU level. Probably, the main reason of this difference was the fact that Spain was facing a critical economic moment in those specific months with the request of financial help from the EU and the fear of an imminent bank collapse in the country. ${ }^{48}$ The midday express press releases were chosen from the European Commission database by individualising the days of the newspapers' articles in order to compare them and analyse how much the newspapers dealt with the EU news. Furthermore, when mentioned in the articles, 60 speeches, statements or memos have been included in the analysis in order to provide evidence of the way national newspapers report the EU officials and institutions' message. The data analysis focused on the common points that characterise online journalism: immediacy, in-depth news (hypertext) and interactivity. ${ }^{49}$ Firstly, the analysis has focused on the graphic features of articles, by briefly illustrating what graphically characterises online newspapers. Afterwards, it focuses on the content covered in the articles. Finally, it concentrates on quantifying the amount of comments appeared below the articles, and the dissemination of articles in the social media was taken under consideration.

\section{ElPais.com and La Repubblica.it: a comparison}

\section{Graphic Features}

Both newspapers have similar graphic features and design. The articles' basic layout in both newspapers always presents a headline, one or two sub-headlines and a picture. Both newspapers show the pictures on the left side or in a central position, and a brief picture description is mentioned below it. The Spanish newspaper often specifies the source of the pictures, while the Italian newspaper does not. Below the sub-headlines El Pais presents the name of the author(s), the

Consensual to a Majoritarian Democracy”. In MUGHAN, Anthony; GUNTHER, Richard - Media and Democracy: a comparative perspective. Cambridge: University Press, 2000. ISBN 978-0-521-77743-8. p. 216.

${ }^{47}$ According to Prisa noticias, a online platform that release news about offline and online media in Spain, El Pais online reached a readership of 7.7 million readers in December 2011. PRISA NOTICIAS - EL PAÍS, online audience leader in Spain. (2012) [Consult. 7 Novembro de 2013]. Disponível em WWW: <URL:http://www.prisanoticias.com/en/sala-de-prensa/el-pais-online-audience-leader-in-spain/>. La Repubblica's online readership reached 1.337 .329 readers in July 2012, making it the first online newspaper read in Italy. TWITTOPOLITICO - La Repubblica stacca il Corriere della Sera e La Stampa: su twitter ha più lettori e un indice di penetrazione più alto (2012) [Consult. 7 Novembro de 2013]. Disponível em WWW: <URL:_http://www.tweetpolitico.it/la-repubblica-stacca-il-corriere-della-sera-e-la-stampa-su-twitter-ha-piu-lettori-e-un-indice-di-penetrazione-piu-alto/

${ }^{48}$ For a further explanation of the Spanish crisis, see section: Spain: a political and socio-economic outlook

${ }^{49}$ For a further explanation of the mentioned features, see section: Features of online news. 
place and the date the article was written, as well as the number of comments about the articles. The articles' length varies from topic to topic, but El Pais usually provides the reader with longer articles. In both newspapers, paragraphs divide the topics in the articles. Importantly, the online edition of the Spanish newspaper shows the hour the article was published and this element is essential as it shows the reader the most updated article based on the exact time the article was released. This element is not visible in La Repubblica, where the authors are rarely mentioned, the location is in the first line of the article and the date is at the very end of the article's text right above the comment box. Another important element worth mentioning is the presence of key words that work as tags in the Spanish articles. ${ }^{50}$ These words immediately outline the main topics discussed in the article and they work as links where readers can be directed to other articles that have covered the similar topic-related news.

Furthermore, the Spanish articles provide readers with the possibility to move to another article or selection of articles related to a topic by embedding links in the texts. La Repubblica, on the other hand, provides article links related to the topic in a box on the left called "Approfondimenti" (in-depth analysis), which in reality are links to related articles. El Pais offers several links to other articles, but at the end of the text. The Spanish articles' layout is also characterised by the presence of quotes from the articles which are highlighted in bold characters on the side of the text. This characteristic is similar to the newspapers' printed version, and it reappears as a graphic element in the digital edition.

The social media icons are positioned in two different places in the layout. In the Spanish newspaper the icons are beside the article on the left, and they show how many times the article has been shared in different platforms. The newspapers provide the reader with the possibility to share the content to: Facebook, Twitter, Google+, Tuenti, Meneame, Eskup. In the Italian newspaper social media icons are positioned above the title and at the end of the article. They also show the number of times the article has been shared. La Repubblica allows users to share the content on Facebook, Twitter, Google+ and Indoona.

\footnotetext{
${ }^{50}$ According to the Oxford Dictionary, tag means "Computing a character or set of characters appended to a piece of text or data in order to identify or categorize it." OXFORD DICTIONARY - Definition of tag in English. [Consult. 18 Outubro de 2013]. Disponível em WWW: <URL: http://www.oxforddictionaries. com/definition/english/tag>.
} 


\section{EU news coverage in ElPais.com and Repubblica.it}

On one side it is clear that both newspapers widely covered the European affairs and decisions related to the crisis during the time-frame selected. On the other side it is also evident that, in the time-frame selected, both newspapers often used a pessimistic tone towards the economic instability, the possible domino effect from Greece and the inability of the EU institutions to assist Europe's recovery from the crisis.

\begin{tabular}{|l|l|}
\hline La Repubblica 15/05/2012 & El Pais 16/05/2012 \\
\hline $\begin{array}{l}\text { Grecia, il ritorno della dracma costerebbe 11 mila euro } \\
\text { all'anno per ogni europeo [Greece, the return to drachma } \\
\text { would cost } € 11 \text { thousands each year to every European] } \\
\text { 'L'Europa si prepara ad alzare il sipario sulla madre di tutte } \\
\text { le tragedie greche: l'addio Atene all'euro' [Europe prepares to } \\
\text { ring up the curtain on the mother of all the Greek tagedies: } \\
\text { Athens' farewell to the euro] }\end{array}$ & $\begin{array}{l}\text { Bruselas redobla las amenazas a Grecia } \\
\text { parte de la familia europea. Pero la solidaridad } \\
\text { y el apoyo europeo son a cambio de reformas, } \\
\text { de sacrificios. No hay una alternativa menos } \\
\text { dolorosa o difícil', ha advertido Barroso. }\end{array}$ \\
$\begin{array}{l}\text { 'Ilprimo atto del possible calvario é già scritto: un fine } \\
\text { settimana, a mercati chiusi, Atene formalizzerà a Bruxelles la } \\
\text { sua uscita dalla moneta unica' [The first act of the possible } \\
\text { ordeal is already written; a weekend, with stock markets } \\
\text { closed, in Brussels, Athens will formalise the exit from the } \\
\text { monetary union] }\end{array}$ & $\begin{array}{l}\text { Tuo o tiene la puerta abierta para irse del club.' } \\
\text { [We want Greece to continue as part of the } \\
\text { European family. But the European solidarity } \\
\text { and support comes in exchange for reforms } \\
\text { and sacrifices. There is no other less painful or } \\
\text { 'Apocalisse' [Apocalypse], Armageddon, 'una Caporetto per } i \\
\text { mercati e una via crucis per Italia e Spagna' [a Caporetto for } \\
\text { the markets and a real trial for Italy and Spain]. }\end{array}$ \\
\hline
\end{tabular}

Generally, newspapers have depicted EU decisions on a national scale and through strong criticism of the EU institutions. Moreover, the reporting of European news was mainly based on the national political agenda as the articles have not always concentrated on Brussels' point of view. The two following articles depict commonalities and differences in the way both newspapers covered the same news. Both articles leave a strong pessimistic message to the reader about the EU institutions at the European Council's eve. 


\begin{tabular}{|c|c|}
\hline blica 27/06/2012 & 1 Pais $27 / 06 / 2012$ \\
\hline $\begin{array}{l}\text { Alla vigilia del vertice europeo di domani, l'economista } \\
\text { greco Yanis Varoufakis scruta l'incaponita ottusita delle } \\
\text { politiche con cui i governi dell'Unione pretendono di } \\
\text { salvare la moneta unica, e si stupisce di fronte a tanto } \\
\text { guazzabuglio dei cuori e delle azioni. Un'attesa quasi } \\
\text { messianica di palingenesi si combina all'abulia dei } \\
\text { politici, alla pigrizia mentale degli economisti, alla } \\
\text { sbalorditiva mancanza di leadership. Ancora una volta } \\
\text { siamo alla vigilia di un vertice definito cruciale. Ci sarà } \\
\text { un prima e un dopo, decideremo cose grandi o fatalmente } \\
\text { naufragheremo. [On the eve of the European summit } \\
\text { tomorrow, the Greek economist Yanis Varoufakis } \\
\text { scans the obstinate policies' vacuity with which EU } \\
\text { governments insist on saving the single currency, } \\
\text { and he is surprised in front of so much mish-mash } \\
\text { of hearts and actions. A wait almost messianic is } \\
\text { combined with the passiveness of politicians, with the } \\
\text { economists' mental laziness, with the stunning lack of } \\
\text { leadership. Once again we are on the eve of a crucial } \\
\text { summit. There will be a before and an after, we will } \\
\text { decide big things or we will fatally wreck] } \\
\text { Non meno inquietante il paragone con la guerra del } \\
\text { Vietnam: negli anni '60-'70, gli uomini del Pentagono } \\
\text { erano già certi della sconfitta. [..] Chi guida oggi } \\
\text { l'Europa è animato dalla stessa non-volontà (l'antico } \\
\text { peccato di nolitio): la crisi delle banche e dei debiti non } \\
\text { è guerra armata, ma certi riflessi sono identici. Il povero } \\
\text { cittadino perde la testa, non si raccapezza. [Not less } \\
\text { disturbing (is) the comparison with the Vietnam War } \\
\text { in the } 60 \text { s and } 70 \text { s, when the Pentagon men were } \\
\text { already certain of defeat. [..] Who leads Europe today } \\
\text { is animated by the same unwillingness (the old sin } \\
\text { of nolitio): the banking crisis and war debts are not } \\
\text { armed, but some reflections are identical. The poor } \\
\text { citizen loses his head, he is at loss] }\end{array}$ & $\begin{array}{l}\text { ¿A la enésima va la vencida? ["to the umpteenth } \\
\text { goes the victory?] } \\
\text { "Tarde y mal, como siempre". Habla en confianza quien } \\
\text { revela lo que realmente se piensa en las instituciones } \\
\text { comunitarias sobre el modo de abordar la crisis que } \\
\text { ha llevado al euro al borde del precipicio. ["Late and } \\
\text { wrong, as usual." The people are able to speak in } \\
\text { confidence about what they really think about the EU } \\
\text { institutions are addressing the crisis that has pushed } \\
\text { the euro to the brink] } \\
\text { "Estamos en un momento critico. Todo está en juego, } \\
\text { incluida la supervivencia de la UE", alerta Herman } \\
\text { van Rompuy, presidente del Consejo Europeo. "No todos } \\
\text { parecen darse cuenta", le secunda José Manuel Duräo } \\
\text { Barroso, presidente de la Comisión. [We are in a critical } \\
\text { moment. Everything is at stake, including the survival } \\
\text { of the EU “, warned Herman van Rompuy, President } \\
\text { of the European Council. Not everybody seems to } \\
\text { realize (the moment)," agrees José Manuel Duräo } \\
\text { Barroso, President of the Commission] } \\
\text { Los lideres europeos repudian en público a sus } \\
\text { mortificadores, como han hecho ante las reacciones } \\
\text { adversas generadas por la indefinición del plan de } \\
\text { salvamento a la banca española. "No vamos a tomar } \\
\text { nuestras decisiones en función de lo que digan los } \\
\text { mercados o las agencias de calificación", declaran una } \\
\text { y otra vez en público dirigentes politicos y portavoces } \\
\text { comunitarios. En privado es otra cosa: "Tarde y mal, } \\
\text { como siempre" [European leaders publicly repudiate } \\
\text { their mortificadores, as they have adverse reactions } \\
\text { to the uncertainty generated by the rescue plan } \\
\text { for the Spanish banking. "We will not make our } \\
\text { decisions based on what the markets or the ratings } \\
\text { agencies say," political representatives and community } \\
\text { spokespersons state again and again. Privately it is } \\
\text { another thing: "late and wrong, as usual."] }\end{array}$ \\
\hline
\end{tabular}

If the characteristics of the Internet are taken under consideration, it is possible to see that the in-depth, or hypertext, feature is different between the newspapers. As a matter of fact, while El Pais includes boxes that explain economic measures, political insights for each country or potential scenarios, La Repubblica's articles are usually brief and synthesise insights in the text itself. Furthermore, the use of external links in the text is usually used by El Pais, but rarely by La Repubblica. Both newspapers often do not use hypertext which is an important tool for online journalism as it provides more space that could be filled with in-depth content or could link to official documents and perhaps to the EU institutions' websites. The connection between the newspapers' websites and the EU documentation has already been used by both newspapers. ${ }^{51}$

${ }^{51}$ An example from the research: In the months analysed, La Repubblica created a link to the official EU document about Italy's budget (LA REPUBBLICA - Ue, peggiora la recessione in Italia "Un aggiustamento per pareggio 2013” Disponível em WWW: <URL:http://www.repubblica.it/economia/2012/05/11/news/ 
However, both editions do not use this procedure consistently, even though it would provide readers with a better understanding of news and it would give them access to the EU official materials. Moreover, El Pais linked readers to other broadsheets' articles where journalists mentioned interviews of EU officials in other newspapers. ${ }^{52}$ Last but not least, the Spanish newspaper sometimes uses videos retrieved from the EC Audiovisual Service, which are publicly available online and can be embedded by the media free of charge. ${ }^{53}$ La Repubblica did not use this service during the selected time-frame of this research, even though it would guarantee more information to the reader and a better understanding of the news from Brussels.

\section{The reception: how online readers commented and shared the news}

During the three months analysed, the articles have been shared through different platforms, with a bigger preference of Facebook and Twitter, compared to other social media. The peak of sharing was reached by El Pais the 10th of June with the article 'España pide un rescate de hasta 100.000 millone para la banca' [Spain asks for a bailout of 100.000 million for the bank]. ${ }^{54}$ The article received 7359 comments, and it was shared 35.189 times on Facebook and 4.425 times on Twitter. The article with the same topic in La Repubblica received no comment and was shared three times on Facebook, and never on Twitter. ${ }^{55}$ In La Repubblica, the article that received most of shares on social media was about the French elections. ${ }^{56}$ On the other hand, El Pais article about Hollande's victory did not receive any comments, but it was shared 6781 times on Facebook and 1695 on Twitter. ${ }^{57}$ The reasons why the articles had

debito_pil_ue_italia_al_123_5_nel_2012-34905939/>. El Pais used this procedure several times, creating links to the official statements and documents of the European Commission and the European Council. For detailed examples of the research, please contact the author.

${ }^{52}$ An example: El Pais published the link of the Wall Street Journal interview of Wolfgang Schäuble. EL PAIS - Hollande reclama "soluciones rápidas" que den oxígeno a los países del sur, 28/06/2012 Disponível em WWW: <URL:http://internacional.elpais.com/internacional/2012/06/28/actualidad/1340913806_336654. html>.

${ }^{53}$ The EBS (European Commission's Audiovisual Service) provides journalists with audiovisual materials, such as videos photos and audio of press conferences and meetings. EC AUDIOVISUAL SERVICE - Mission. [Consult. 20 Novembro de 2013]. Disponível em WWW: <URL: http:// ec.europa.eu/avservices/about/index.cfm?sitelang=en $>$.

${ }^{54}$ Example from the research: EL PAIS - España pide un rescate de hasta 100.000 millones para la banca, 10/06/2012. Disponível em WWW: <URL:http://economia.elpais.com/economia/2012/06/09/ actualidad/1339230670_176850.html>.

${ }^{55}$ Example: LA REPUBBLICA - Rehn: "Gli aiuti alla Spagna messaggio chiaro per i mercati”. 10/06/2015 Disponível em WWW: <URL: http://www.repubblica.it/economia/2012/06/10/news/ spagna_aiuti_rehn_chiaro_messaggio_mercati-36940797/>.

${ }^{56}$ Example from the research: LA REPUBBLICA - Hollande trionfa: "Ora la crescita"Laddio di Sarkozy: “Colpa mia”, 06/05/2012 Disponível em WWW: <URL: http://www.repubblica.it/esteri/2012/05/06/news/ francia_risultati-34565294/>.

${ }^{57}$ Example from the research: EL PAIS - Hollande: "La austeridad no puede ser una condena”. 07/05/2012 Disponível em WWW: <URL: http://internacional.elpais.com/internacional/2012/05/06/actualidad/1336324748_613508.html>. 
great diffusion through social media was probably due to the importance the topics had in national public opinions.

Both newspapers follow a commenting policy which prevents users from commenting with negative and inappropriate words by moderating the discussion and deleting impolite comments. The registration in both newspapers is easy and requires a login with an email address. As soon as users receive a confirmation email, they can write their comments. In the three months analysed, an evident difference was noticeable during the comparison of the newspapers. While almost all the articles analysed in El Pais received several comments, in La Repubblica the only article that received comments was one related to the Schengen treaty. ${ }^{58}$ Since commenting on the articles was easily accessible, the lack of comments featuring in the Italian newspaper was not due to a severe monitoring of the comments. Also, through monitoring La Repubblica's website, it is possible to state that users comment news about national politics or social issues on a large scale, therefore it is possible to deduce that La Repubblica's readers are keener on commenting and interacting about national news rather than EU ones.

\section{Conclusions}

The Eurozone crisis is one of the most difficult realities for the European Union. Still nowadays the EU institutions are adopting measures and solutions in order to recover from a crisis that is considered the worst one since the creation of the Union. In this specific political and economic moment, the coverage of EU news increased due to several meetings and summits organised by the EU and international bodies. Unfortunately, as this research confirmed, the majority of the EU news covered mainly negative events and incidents or strict measures decided in Brussels. Furthermore, the perspective of the news' depiction still exhibits a national angle or the news framed viewpoints relatively take into consideration a European analysis of the events. Besides that, through observing the analysed articles, it is important to underline how Berlin's statements have become more and more the focus of attention. ${ }^{59}$ What also seems visible among the articles, is a strong search for conflicts, inside stories, and argumentative opinions of national and European officials that are reported by journalists. Brussels is often used as synonymous for the European Commission and often regarded as a place where EU sources report stories that EU institutions do not confirm. The city symbol of the Union is often blamed for being unable to solve the Eurozone crisis. ${ }^{60}$

Moreover, their transition from offline to online platforms seemed not to be completed during the period analysed, as the articles sometimes seemed to be reproductions of printed versions. However, both editions showed their efforts in

\footnotetext{
${ }^{58}$ Example from the research: LA REPUBBLICA - Schengen, sospeso il trattato L'Europa si difende dai migranti 07/06/2012. Disponível em WWW: <URL: http://www.repubblica.it/solidarieta/immigrazione/2012/06/07/news/shengen_sospeso_il_trattato_1_europa_si_difende_dai_migranti-36766753/>.

${ }^{59}$ This research was part of the Master Thesis 'Online news coverage of the Eurozone crisis: discussion and reception in Italy and Spain'. For detailed examples of articles in La Repubblica and El Pais regarding the focus on the German opinions, please contact the author, mail: alb.martalb@gmail.com

${ }^{60}$ For detailed examples, see note 59
} 
using online features, as they published videos and allowed users to share articles on social media, as well as allowing them to comment below articles by creating a place for discussion.

According to Örnebring, journalism becomes European when it "covers subject matters from a European (rather than national) point of view, and that therefore, also addresses its audience explicitly as European". ${ }^{61}$ This implies not only a necessary presence of European news in national media, but a deep European vision in the way news is covered. The constitution of European Journalism would encourage citizens to better understand the role of the institutions and perhaps become more interested in the Union, especially in moments of political instability and economic uncertainty. However, this research confirms that, during the time-frame selected and the fact that both online editions dealt with European news on a daily basis, the online platforms of El Pais and La Repubblica still reflected a strong national perspective and did not provide a neutral and objective European point of view.

\section{Acknowledgements}

I thank Dr. Luciano Morganti for assisting me during the theoretical and research phases of this article, and always providing me with constructive advices.

\section{Bibliography}

ALLAN, Stuart - "The emerging forms and practices of online journalism". In ALLAN, Stuart - Journalism: critical issues. Berkshire: Open Universiy Press, 2005. ISBN 0335214754.

ALLAN, Stuart - Online News, Journalism and The Internet. London: McGraw Hill Education. 2006. ISBN 100335221211.

BAISNEE, Olivier - "Can Political journalism exist at the EU level?". In KUHN, Raymond; NEVEN, Eric. - Political Journalism - New challenges, new practices. London: Routledge, 2002. ISBN 0-415-25813-8. p. 115.

BOCKZKWSKI, Pablo Javier - Digitizing the news - Innovation in online newspapers. Cambridge: MIT Press paperback edition, 2005. ISBN 9780262524391. p. 3-5 and ALLAN, Stuart Online News, Journalism and The Internet. London: McGraw Hill Education, 2006. ISBN 10033522121 1. p. 23-26

CARBALLO-CRUZ, Francisco - "Causes and Consequences of the Spanish Economic Crisis: Why the Recovery is Taken so Long?”. PANOECONOMICUS. 2011, 3, (2011) p. 309. [Consult. 30 Setembro de 2013]. Disponível em WWW: <URL:http://www.doiserbia.nb.rs/ $\mathrm{img/doi/1452-595X/2011/1452-595X1103309C.pdf} \mathrm{>}$

${ }^{61}$ ÖRNEBRING, Henrik - Comparative European Journalism: The State of Current Research. Oxford: working Paper of Reuters Institute for the study of journalism, (2009) p. 8 [Consult. 2 Novembro de 2013]. Disponível em WWW: <URL:http://snap3.uas.mx/RECURSO1/LibrosElectronicos/BIBAS\%20 PERIODISMO\%20-\%20DIGITAL/Comparative_European_Journalism_HO_Working_Paper_01.pdf>. 
CASTELLS, Manuel; PARKS, Micheal; VAN DER HAAK, Bregtje - "The Future of Journalism: Networked Journalism”. International Journal of Communication. 6 (2012). Feature 29232938. p. 2933-2934. [Consult. 6 de Agosto de 2013]. Disponível em WWW: <URL: http:// ijoc.org/index.php/ijoc/article/viewFile/1750/832>.

CENCIG, Elisa - "Italy's economy in the euro zone crisis and Monti's reform Agenda". SWF Berlin Working Paper. FG 1 2012/05 (September 2012) p.3 [Consult. 6 Outubro de 2013]. Disponível em WWW: <URL: http://www.swp-berlin.org/fileadmin/contents/products/ arbeitspapiere/Italy_Economy.pdf $>$.

CENCIG, Elisa - "Italy's economy in the euro zone crisis and Monti's reform Agenda". SWF Berlin Working Paper. FG1 2012/05. (2012) p.8. [Consult. 6 Outubro de 2013]. Disponível em WWW: <URL:http://www.swp-berlin.org/fileadmin/contents/products/arbeitspapiere/ Italy_Economy.pdf>.

CENCIG, Elisa - Italy's economy in the euro zone crisis and Monti's reform Agenda. SWF Berlin: Working Paper FG 1 2012/ 05. (2012) p. 33 [Consult. 6 Outubro de 2013]. Disponível em WWW: <URL: http://www.swp-berlin.org/fileadmin/contents/products/ arbeitspapiere/Italy_Economy.pdf >

CORNIA, Alessio - "The Europeanization of Mediterranean Journalistic practices and the Italianization of Brussels: Dynamics of the interaction between EU institutions and nationalistic cultures". European Journal of Communication. Vol. 25, No4 (2010) p. 366 [Consult. 1 Março de 2013]. Disponível em WWW: <URL:http://ejc.sagepub.com/ content/25/4/366.full.pdf >

CORNIA, Alessio - "The Europeanization of Mediterranean Journalistic practices and the Italianization of Brussels: Dynamics of the interaction between EU institutions and nationalistic cultures". European Journal of Communication. 25: 366 (2010) [Consult. 1 Março de 2013]. Disponível em WWW: <URL:http://ejc.sagepub.com/content/25/4/366.full.pdf>.

COUNCIL OF THE EUROPEAN UNION - Eurogroup Statement on Spain. (2012) [Consult. 23 Setembro de 2013]. Disponível em WWW: <URL:http://www.consilium.europa.eu/ uedocs/cms_data/docs/pressdata/en/ecofin/130778.pdf >

DE VREESE, Claes H. - "The EU as a public sphere". Living Reviews in European Governance. Vienna. ISSN 1813-856X. N. 03, Vol. 2 (2007) p. $7-8$

DI QUIRICO, Roberto - "Italy: the good, the bad and the ugly". Bulletin of Italian Politics. Vol. 2, No. 2, (2010) p. 3-19 [Consult. 7 Outubro de 2013]. Disponível em WWW: <URL: http://www.gla.ac.uk/media/media_191024_en.pdf>.

DOMINGO, David [et al.] - "Participatory Journalism Practices in the media and beyond - An international comparative study of initiatives in online newspapers". Journalism Practice. ISSN 1751-2786. Vol. 2, No 3 (2008).

DONADIO, Rachel - "As a Premier Prepares to Depart, the Talk Is of Lost Opportunities". New York Times. Dec. 3 (2012) [Consult. 6 Outubro de 2013]. Disponível em WWW: <URL: http://www.nytimes.com/2012/12/14/world/europe/as-mario-monti-prepares-tostep-down-italians-express-disappointment.html?ref=topics >

EC AUDIOVISUAL SERVICE - Mission. [Consult. 20 Novembro de 2013]. Disponível em WWW: <URL: http://ec.europa.eu/avservices/about/index.cfm?sitelang=en>.

EL PAIS - "La manifestación de 'indignados' reúne a varios miles de personas en toda España". (2011) [Consult. 6 Setembro de 2013]. Disponível em WWW: <URL: http://elpais.com/ elpais/2011/05/15/actualidad/1305447428_850215.html >. 
EL PAIS - España pide un rescate de hasta 100.000 millones para la banca, 10/06/2012. Disponível em WWW: <URL:http://economia.elpais.com/economia/2012/06/09/ actualidad/1339230670_176850.html>.

EL PAIS - Hollande reclama "soluciones rápidas" que den oxígeno a los países del sur, 28/06/2012 Disponível em WWW: <URL:http://internacional.elpais.com/internacional/2012/06/28/ actualidad/1340913806_336654.html>.

EL PAIS - Hollande: "La austeridad no puede ser una condena". 07/05/2012. Disponível em WWW: <URL: http://internacional.elpais.com/internacional/2012/05/06/actualidad/1336324748_613508. html>.

Europa Press Room, European Commission Press Releases and the European institutions in EUROPEAN COMMISSION, Europa Press Room. (2013) [Consult. 2 Fevereiro de 2013]. Disponível em WWW: <URL:http://europa.eu/rapid/midday-express.htm>.

EUROPEAN COMMISSION - "Media Use in the European Union". TNS Opinion \& Social - Standard Eurobarometer 76 (Autumn 2011) p.29-31. [Consult. 22 Setembro de 2013]. Disponível em WWW: <URL: http://ec.europa.eu/public_opinion/archives/eb/eb76/ eb76_media_en.pdf>

EUROSTAT - "Unemployment Statistics". (2012). [Consult. 25 Setembro de 2013]. Disponível em WWW: <URL:http://epp.eurostat.ec.europa.eu/statistics_explained/index.php/ Unemployment_statistics>.

FINANCIAL TIMES - Spain to inject $€ 19$ bn into Bankia, (2012) [Consult. 30 Setembro de 2013]. Disponível em WWW: <URL:http://www.ft.com/intl/cms/s/0/27db02ec-a643-11e1aef2-00144feabdc0.html\#axzz2gqqACvn4>

GUNTHER, Richard; MONTERO, José Ramon; WERT, Jose Ignacio - "The media and politics in Spain: from Dictatorship to Democracy". In MUGHAN, Anthony; GUNTHER, Richard - Media and Democracy: a comparative perspective. Cambridge: University Press, 2000. ISBN 978-0-521-77743-8. p. 45

HALLIN, Daniel C.; MANCINI, Paolo - Modelli di giornalismo. Mass media e politica nelle democrazie occidentali. Trad. Silvia Marini. Roma - Bari: Laterza, 2004. ISBN 88-420-7444-6.

HIDALGO, Juan Carlos - Looking at Austerity in Italy. Cato Institute. (2012) [Consult. 6 Outubro de 2013]. Disponível em WWW: <URL: http://www.cato.org/blog/lookingausterity-italy>

LA REPUBBLICA - Hollande trionfa: "Ora la crescita"L'addio di Sarkozy: "Colpa mia". 06/05/2012. Disponível em WWW: <URL: http://www.repubblica.it/esteri/2012/05/06/ news/francia_risultati-34565294/>.

LA REPUBBLICA - Rehn: "Gli aiuti alla Spagna messaggio chiaro per i mercati". 10/06/2015 Disponível em WWW: <URL: http://www.repubblica.it/economia/2012/06/10/news/ spagna_aiuti_rehn_chiaro_messaggio_mercati-36940797/>.

LA REPUBBLICA - Schengen, sospeso il trattato L'Europa si difende dai migranti, 07/06/2012 Disponível em WWW: <URL: http://www.repubblica.it/solidarieta/immigrazione/2012/06/07/ news/shengen_sospeso_il_trattato_1_europa_si_difende_dai_migranti-36766753/>.

LA REPUBBLICA - Ue, peggiora la recessione in Italia "Un aggiustamento per pareggio 2013" Disponível em WWW: <URL:http://www.repubblica.it/economia/2012/05/11/news/ debito_pil_ue_italia_al_123_5_nel_2012-34905939/>.

LECHELER, Sophie, MARTINS, Ana Isabel, DE VREESE, Claes H. - "Information Flow and Communication Deficit: Perceptions of Brussels-Based Correspondents and EU 
Officials". Journal of European Integration. Vol. 34 (2012) p. 316. [Consult. 9 Agosto de 2013]. Disponível em WWW: <URL:http://dx.doi.org/10.1080/07036337.2011.584345>

MARLETTI, Carlo; RONCAROLO, Franca - "Media Influence in the Italian Transition From a Consensual to a Majoritarian Democracy". In MUGHAN, Anthony; GUNTHER, Richard - Media and Democracy: a comparative perspective. Cambridge: University Press, 2000. ISBN 978-0-521-77743-8. p. 216.

MCCORMICK, John - Understanding the European Union. New York: Palgrave Macmillan. 2008. ISBN 978-0-230-20102-6. p. 4-5

MÖRÄ, Tuomo - "Ideals of European Public Sphere and EU Journalism". Sociologija. Mintis ir veiksmas. ISSN 1392-3358. 2008/3 (23) (2008) p. 88. [Consult. 4 Dezembro de 2012]. Disponível em WWW: <URL: file://C:/Users/UTENTE-PC/Downloads/CEEOL\%20 Article.PDF>,

MOUSSIS, Nicholas - Access to the European Union - Law, economics, policies. Brussels: Euroconfidential, 2011. ISBN 978-2-9601045-0-9. p. 177

ÖRNEBRING, Henrik - Comparative European Journalism: The State of Current Research. Oxford: working Paper of Reuters Institute for the study of journalism, (2009) p. 8 [Consult. 2 Novembro de 2013]. Disponível em WWW: <URL:http://snap3.uas.mx/RECURSO1/ LibrosElectronicos/BIBAS\%20PERIODISMO\%20-\%20DIGITAL/Comparative_European_ Journalism_HO_Working_Paper_01.pdf>.

OXFORD DICTIONARY - Definition of tag in English. [Consult. 18 Outubro de 2013]. Disponível em WWW: <URL: http://www.oxforddictionaries.com/definition/english/tag>.

PRISA NOTICIAS - EL PAÍS, online audience leader in Spain. (2012) [Consult. 7 Novembro de 2013]. Disponível em WWW: <URL:http://www.prisanoticias.com/en/sala-de-prensa/ el-pais-online-audience-leader-in-spain/>.

SIMON, Jean Paul - "The Newspaper Publishing Industry, Statistical, Ecosystems and Competitiveness Analysis of the Media and Content Industries". Joint Research Centre. Luxembourg. ISSN 1831-9424. Report EUR 25277 EN (2012) p. 43.

STATHAM, Paul - "Make Europe News - How journalists view their role and media performance". Journalism. Vol. 9(4). (2008) p. 417 - 418 [Consult. 7 Dezembro de 2012]. Disponível em WWW: <URL:http://jou.sagepub.com.ezproxy.vub.ac.be:2048/content/9/4/398.full. pdf + html $>$

STATHAM, Paul - "Political Journalism and Europeanization: Pressing Europe?". Centre for European Political communication, Working Paper Series. Issue 13/06 (2006) p. 10. [Consult. 1 Agosto de 2013]. Disponível em WWW: <URL:http://www.eurpolcom.eu/exhibits/ paper_13.pdf >

STATHAM, Paul - "Political Journalism and Europeanization: Pressing Europe?". Centre for European Political communication, Working Paper Series. Issue 13/06 (2006) p. 31-33 [Consult. 1 Agosto de 2013]. Disponível em WWW: <URL:http://www.eurpolcom.eu/ exhibits/paper_13.pdf >

STEENSEN, Steen - "Online Journalism and the promises of new technologies - A critical review and look ahead”. Journalism Studies. 12:3 (2010) p. 320. [Consult. 7 Setembro de 2013]. Disponível em WWW: <URL: http://dx.doi.org/10.1080/1461670X.2010.501151>

SUAREZ, Javier - "The Spanish Crisis: Background and Policy Challenges". CEMFI. (2010) p. 5 [Consult. 25 Setembro de 2013]. Disponível em WWW: <URL: http://www.cemfi. es/-suarez/The_Spanish_Crisis_JSuarez.pdf> 
THE NEW YORK TIMES - Spain to accept rescue from Europe for its ailing banks. (2012) [Consult. 24 Setembro de 2013]. Disponível em WWW: <URL:http://www.nytimes.com/2012/06/10/ business/global/spain-moves-closer-to-bailout-of-banks.html? pagewanted=all $>$.

TRENZ, Hans-Jörg - "Quo vadis Europe?” Quality newspapers struggling for European unity. Paper presented at the Workshop "One EU - Many Publics?". Stirling 5 - 6 February 2004. p. 18 [Consult. 7 Dezembro de 2012]. Disponível em WWW: <URL:http://www.sv.uio.no/ arena/english/research/projects/cidel/old/WorkshopStirling/PaperTrenz.pdf >

TWITTOPOLITICO - La Repubblica stacca il Corriere della Sera e La Stampa: su twitter ha più lettori e un indice di penetrazione più alto (2012) [Consult. 7 Novembro de 2013]. Disponível em WWW: <URL: http://www.tweetpolitico.it/la-repubblica-stacca-il-corrieredella-sera-e-la-stampa-su-twitter-ha-piu-lettori-e-un-indice-di-penetrazione-piu-alto/

VAN DE STEEG, Marianne - "Does a public sphere exist in the European Union? An analysis of the content of the debate on the Haider case". European Journal of Political Research. Vol. 45, Nr. 4 (2006) p. 610-611. [Consult. 7 Dezembro de 2012]. Disponível em WWW: <URL: http://onlinelibrary.wiley.com.ezproxy.vub.ac.be:2048/doi/10.1111/j.14756765.2006.00311.x/pdf>. 